\title{
Plasma-Treated Flammulina velutipes-Derived Extract Showed Anticancer Potential in Human Breast Cancer Cells
}

\author{
Sarmistha Mitra ${ }^{1,+}{ }^{,}$Pradeep Bhartiya ${ }^{1,+}$, Neha Kaushik ${ }^{2,+}+\mathbb{C}$, Linh Nhat Nguyen ${ }^{1}$, \\ Rizwan Wahab ${ }^{3}$, Sander Bekeschus ${ }^{4}$ (D), Eun Ha Choi ${ }^{1, *(D)}$ and Nagendra Kumar Kaushik $1, *(\mathbb{D})$ \\ 1 Plasma Bioscience Research Center/Applied Plasma Medicine Center, \\ Department of Electrical and Biological Physics, Kwangwoon University, Seoul 01897, Korea; \\ sarmisthacu@gmail.com (S.M.); pradeepbhartiya@kw.ac.kr (P.B.); linhnn@ims.vast.ac.vn (L.N.N.) \\ 2 College of Engineering, Department of Biotechnology, University of Suwon, Hwaseong 18323, Korea; \\ neha.bioplasma@suwon.ac.kr \\ 3 College of Science, Department of Zoology, King Saud University, Riyadh 11451, Saudi Arabia; \\ rwahab@ksu.edu.sa \\ 4 Centre for Innovation Competence (ZIK) Plasmatis, Leibniz Institute for Plasma Science and Technology \\ (INP Greifswald), 17489 Greifswald, Germany; sander.bekeschus@inp-greifswald.de \\ * Correspondence: ehchoi@kw.ac.kr (E.H.C.); kaushik.nagendra@kw.ac.kr (N.K.K.) \\ + These authors equally contributed to this work.
}

Received: 9 October 2020; Accepted: 22 November 2020; Published: 25 November 2020

\begin{abstract}
Natural products with medicinal properties are among alternative therapies of interest due to their high body tolerance. We aimed to determine whether nonthermal gas plasma could enhance the medicinal value of Flammulina velutipes mushrooms. Generated gas plasma was characterized by its emission spectrum in ambient air, $\mathrm{pH}$, temperature, and $\mathrm{H}_{2} \mathrm{O}_{2}$ and $\mathrm{NO}_{\mathrm{x}}$ concentrations after exposure for various periods. Phenolic and flavonoid contents in the extracts were measured using antioxidant assays and Fourier transform infrared and ultraviolet-visible spectroscopy. We analyzed the effects of the plasma-treated mushroom-derived extracts against breast carcinoma using the MCF7 and MDA-MB231 cell lines. The extracts significantly and concentration dependently inhibited the growth of breast cancer cells without inducing toxicity in normal MCF10A cells, and induced apoptosis via oxidative stress, evidenced by DNA damage ( $\gamma$-H2AX foci formation), and increased the population of MCF7 breast cancer cells arrested in the G2/M phase of the cell cycle. The extracts also induced mitochondrion-mediated apoptosis of MCF7 cells through cytochrome c release and caspase cleavage activity. The plasma improved the biological activity of mushrooms by increasing their phenolic compounds that prevented the growth of breast cancer cells in vitro.
\end{abstract}

Keywords: gas plasma; mushroom; anticancer; cell death

\section{Introduction}

Breast cancer remains one of the biggest challenges to medical research because it is the most common malignancy and leading cause of death among women. Conventional treatments can cause several side effects and generate resistance toward therapeutics, and therefore alternative approaches to cancer treatment are garnering more attention, and natural products in alternative therapies and cancer management strategies are gaining more popularity [1]. Mushrooms are a readily available, functional food with several health benefits and phytoconstituents. Currently, Flammulina velutipes (F. velutipes) is one of the four most widely cultivated mushrooms worldwide, because of its taste and high nutritional value. Additionally, its consumption can confer a wide variety of health-promoting 
effects, including immunity enhancement and reduced blood cholesterol levels and pressure, as well as chemopreventative benefits. This is owing to its bioactive constituents [2]. Although extracts of this mushroom are significantly active against different breast cancer cell lines due to its antioxidant properties [3], it has not been comprehensively studied. The nutritional value of mushrooms is highly dependent on the cultivation method. The primary objective behind the cultivation strategy of any organic product is to boost its yield. Currently, an agricultural support system that helps increase production with minimal environmental side effects is required. Plasma has practical applications in the agricultural and food industries, and the contributory role of nonthermal plasma to agriculture has been established [4-6]. An increase in mushroom growth induced by nonthermal gas plasma (NTP) might be exploited to further enhance crop yield.

Generally, reactive species and other plasma-induced components contribute to initiating growth mechanism or signaling direct plasma treatment. Plasma discharge can create neutral atoms and molecules, radicals, excited states, ions, and electrons, together with electrical energy [7]. These energetic electrons can generate radicals, charged species, excited states, and ultraviolet photons. With these unique properties, NTP sources can create a chemically productive environment. Without increasing the temperature, plasma generates an exclusive environment in which highly reactive plasma species can be delivered in a nondestructive and beneficial way to biological samples $[8,9]$. Studies have highlighted the various pharmacological properties of F. velutipes such as antimicrobial [10], anti-inflammatory [11], antioxidant [2], and immunomodulatory [12] and anticancer [2,12] activities. Water-based extracts of $F$. velutipes can inhibit growth and induce apoptosis in breast cancer cells [13]. Moreover, whole extracts or their purified components, such as polysaccharides and sterols, can affect cancer cell migration, inhibit growth, and exert immunomodulatory activities [14-16]. Due to the safety associated with plasma, exposing natural products such as F. velutipes to gas plasma to enhance its phytochemical properties, as well as yield, is rapidly gaining popularity. This study aimed to determine the effectiveness of plasma-treated mushroom-derived extracts on breast cancer cells with safety considerations for their normal counterparts.

\section{Materials and Methods}

\subsection{Characterization of Gas Plasma}

Figure 1A shows a schematic of the soft plasma jet employed in this study, which used ambient air as the feeding gas, at an operating voltage of $2 \mathrm{kV}$. Optical emission spectroscopy (OES) of the soft plasma jet plume was measured using an Ocean Optic HR4000CG-UV-NIR spectrometer (Ocean Insight, Orlando, FL, USA). Figure 1B shows the plasma OES spectrum with strong emission lines of reactive oxygen and nitrogen species (RONS). For instance, the prominent emission of nitrogen second positive system ( $\left.\mathrm{N}_{2} \mathrm{SPS}\right)$, nitrogen first negative system ( $\left.\mathrm{N}_{2} \mathrm{FNS}\right)$, and $\mathrm{NO}$ were observed in the $310-380 \mathrm{~nm}, 400-450 \mathrm{~nm}$, and $200-300 \mathrm{~nm}$ range, respectively. The emission of $\mathrm{OH}$ radicals was detected at $306.67 \mathrm{~nm}$. In addition, several prominent atomic emission lines were observed, including $\mathrm{H} \alpha(656.13 \mathrm{~nm}), \mathrm{N}(746.68,821.17$, and $867.88 \mathrm{~nm})$, and $\mathrm{O}(777.08$ and $844.08 \mathrm{~nm})$. To standardize plasma discharge conditions, we measured the media $\mathrm{pH}$ and temperature, and the results showed no significant increase with prolonging treatment time (Figure 1C,D). 
A

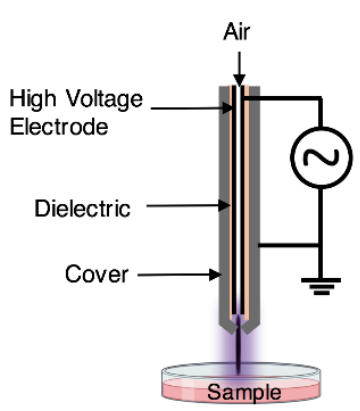

D

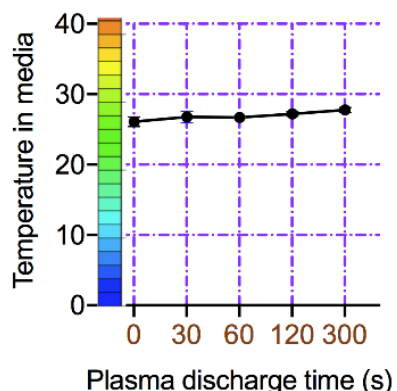

B

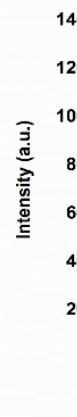

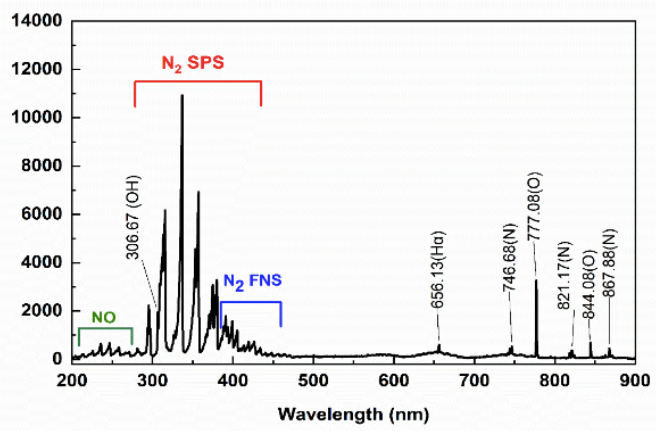

E

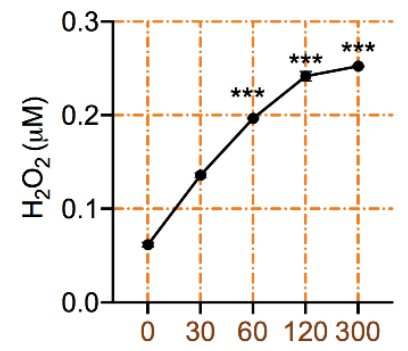

Plasma discharge time (s)
C

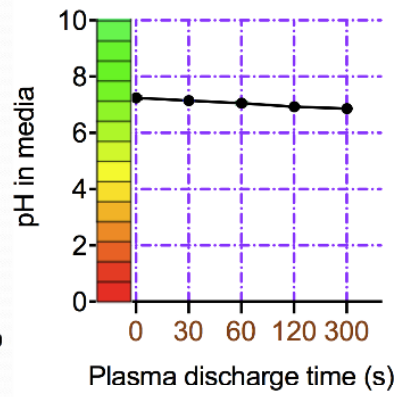

$\mathrm{F}$

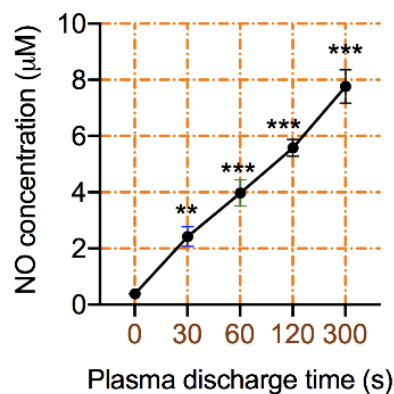

Figure 1. Characterization and standardization of plasma device. (A) Schematic of air gas jet plasma device; (B) Optical emission spectrum of plasma-generated species in ambient air; (C,D) $\mathrm{pH}$ and temperature of media after exposure to plasma for various periods, respectively; (E,F) Determination of $\mathrm{H}_{2} \mathrm{O}_{2}$ and $\mathrm{NO}_{x}$ concentrations in medium after plasma exposure for indicated periods. ${ }^{* *} p<0.01$ and ${ }^{* * *} p<0.001$.

\section{2. $\mathrm{H}_{2} \mathrm{O}_{2}$ Level, $\mathrm{NO}_{x}$ Level, Temperature, and $\mathrm{pH}$ Measurement}

To investigate the effect of plasma treatment on oxidative and acidic modification, $\mathrm{ROS}_{(}\left(\mathrm{H}_{2} \mathrm{O}_{2}\right.$ and $\mathrm{NO}_{\mathrm{x}}$ ) concentration and $\mathrm{pH}$ of the water were measured at different treatment times. In our experiment, $\mathrm{pH}$ was measured using a $\mathrm{pH}$ meter. The QuantiChrom ${ }^{\mathrm{TM}}$ Nitric Oxide Assay Kit (BioAssay Systems, Hayward, CA, USA) and the Amplex ${ }^{\mathrm{TM}}$ Red Hydrogen Peroxide/Peroxidase Assay Kit (Molecular Probes, Eugene, OR, USA) were used, respectively, to determine $\mathrm{NO}_{x}$ and $\mathrm{H}_{2} \mathrm{O}_{2}$ concentrations. All detection steps were performed, according to the manufacturers' protocols. Temperature and $\mathrm{pH}$ in PBS were recorded using an IR digital camera (TI90-Fluke Instruments, Everett, WA, USA) and pH meter ( $\mathrm{pH}$ spear by Coretech), respectively.

\subsection{Mushroom Cultivation and Plasma Application}

Mushrooms were cultivated in the laboratory in a temperature-controlled chamber (Sejong Plus, SJP 110308-7, Seoul, Korea) using potato dextrose agar (PDA) as a growth medium. Cultivation was at $25{ }^{\circ} \mathrm{C}$ and $50 \%$ humidity for the first six weeks, and at $4{ }^{\circ} \mathrm{C}$ for the following four weeks. To maintain humidity, water was occasionally sprayed, and water-soaked paper towels were stored inside the chamber. A plasma jet device using air gas $\left(1.5 \mathrm{~L} \mathrm{~min}^{-1}\right)$ was employed in this study. Three different treatment times $(30,60$, and $120 \mathrm{~s})$ were used to treat the culture samples every week, and the distance from the plasma actuator to the sample surface was maintained at $5 \mathrm{~cm}$. The sample was treated once a week for up to 10 weeks. 


\subsection{Collection of Material}

After 10 weeks, the matured fruiting bodies from all culture plates were harvested by slicing the base just above the surface of the medium using a sharp blade.

\subsection{Mushroom Extract Preparation}

Harvested mushrooms were freeze-dried using liquid nitrogen and ground to a fine powder. Powdered plant material $(1000 \mathrm{mg})$ from each of the two different plasma treatment groups $(30 \mathrm{~s}$ and $60 \mathrm{~s}$ ) and from the untreated group was weighed and soaked in $5 \mathrm{~mL}$ of $5 \%$ ethanol for $48 \mathrm{~h}$. Then, the resulting extracts were filtered using Whatman No. 1 filter paper and dried (Figure 2A). Finally, $50 \mathrm{mg}$ of dried extracts were weighed for each sample and a $25 \mathrm{mg} \mathrm{mL}^{-1}$ stock solution was prepared and stored at $4{ }^{\circ} \mathrm{C}$. This stock solution was further diluted with distilled water to prepare a sub-stock solution of $1 \mathrm{mg} \mathrm{mL}^{-1}$. The mushroom extract stock solution was used at concentrations of $1000,500,200,100,50$, and $10 \mu \mathrm{g} \mathrm{mL} \mathrm{m}^{-1}$ to treat cancer and normal cells, and cells were harvested based on the relevant experimental conditions.

A

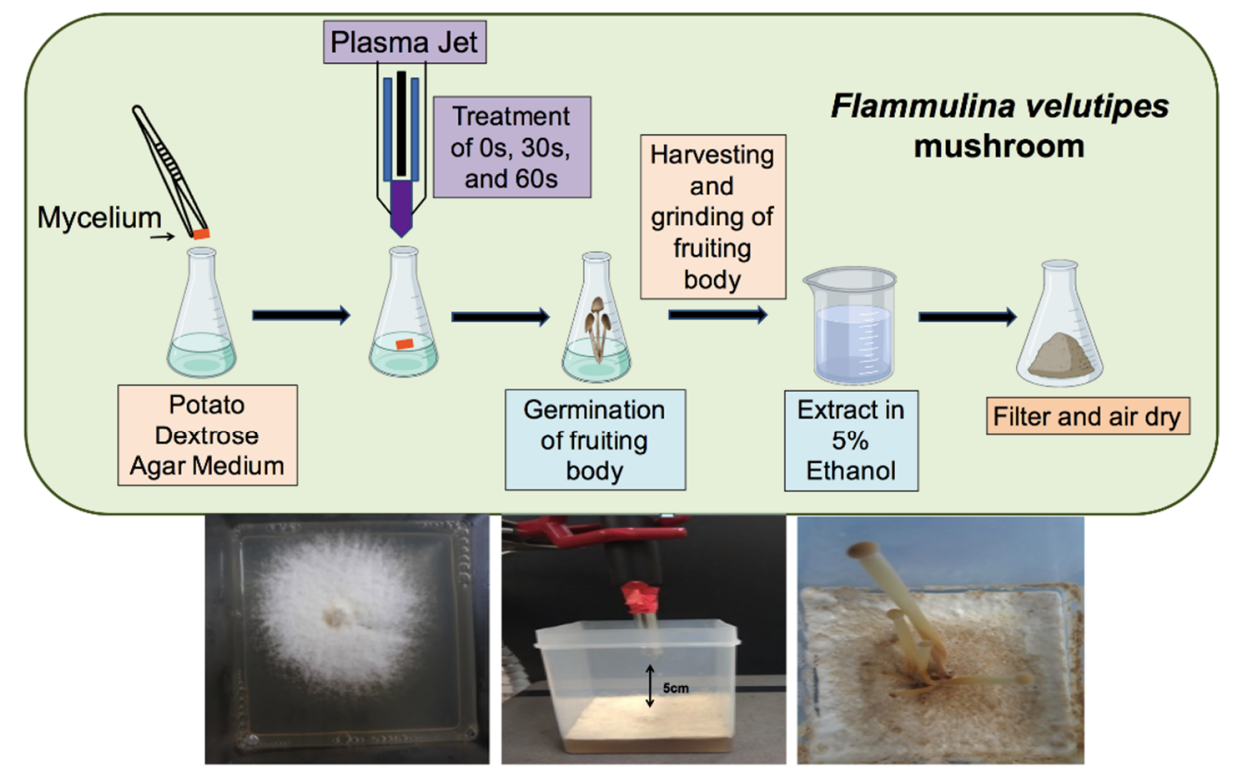

B

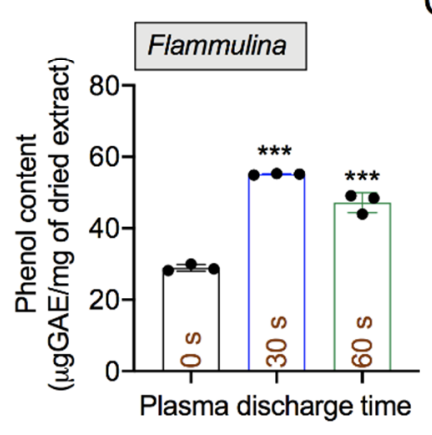

C

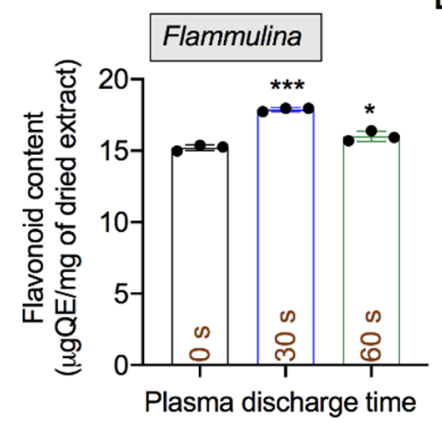

D

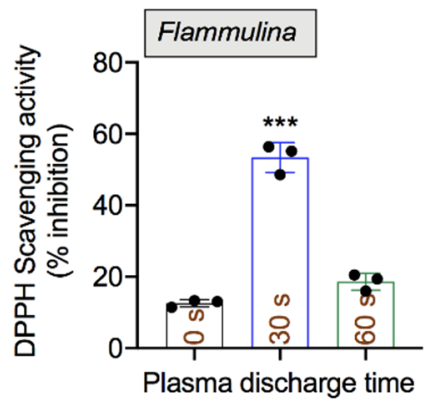

Phytochemical analysis

Figure 2. Extract preparation from plasma-treated/untreated mushrooms (F. velutipes) and their characterization. (A) Experimental scheme for extract preparation from plasma-exposed and unexposed mushroom; (B-D) Measurement of phenolic, flavonoid, and antioxidant properties in extracts prepared from plasma-treated (30 s and $60 \mathrm{~s}$ ) and untreated (0 s) mushrooms. ${ }^{*} p<0.05$ and ${ }^{* * *} p<0.001$. Untreated sample was used as a negative control for normalization. 


\subsection{Characterization of Mushroom Extract}

\subsubsection{FTIR and UV-Vis Analysis}

Fourier transform infrared spectroscopy (FTIR) and ultraviolet-visible (UV-Vis) spectroscopy were used to investigate the presence of active constituents in the extract. The mushroom extract was placed in the infrared beam output of the FTIR spectrometer (Jasco FT/IR 4000). Analysis of the obtained oscillatory spectra determined the functional groups with which the radiation interacted. UV-Vis spectrum of the extract was recorded from diluted extract $\left(1 \mathrm{mg} \mathrm{mL}^{-1}\right)$. The mixture was scanned using a circular dichroism spectrophotometer (Jasco J-815, JASCO, Tokyo, Japan).

\subsubsection{Phenol Content}

The total phenol content of the extract was determined using the Folin-Ciocalteu colorimetric method $[17,18]$. Gallic acid was used as a standard. Different concentrations of gallic acid were prepared as standard solutions $\left(0-300 \mathrm{~g} \mathrm{~L}^{-1}\right)$, and the calibration curve was established using gallic acid. The test sample $(0.2 \mathrm{~mL})$ was mixed with $0.6 \mathrm{~mL}$ of water and $0.2 \mathrm{~mL}$ of Folin-Ciocalteu phenol reagent (1:1). After $5 \mathrm{~min}, 1 \mathrm{~mL}$ of saturated sodium carbonate solution ( $8 \% \mathrm{w} / \mathrm{v}$ in water) was added to the mixture, and the volume brought to $3 \mathrm{~mL}$ with distilled water. The reaction was incubated at room temperature for $30 \mathrm{~min}$ in the dark, and the absorbance from different samples was measured at $750 \mathrm{~nm}$. Results were expressed as micrograms of gallic acid equivalent (GAE)/50 mg dry weight.

\subsubsection{Flavonoid Content}

The aluminum chloride colorimetric method was used to determine the total flavonoid content of each sample [19]. Quercetin was used to prepare the standard curve for calibration. A stock solution was prepared by dissolving $5.0 \mathrm{mg}$ of quercetin in $1.0 \mathrm{~mL}$ of methanol, and then standard solutions were prepared by serial dilutions using methanol. Crude extract $(100 \mu \mathrm{L})$ was made up to $1 \mathrm{~mL}$ with methanol and mixed with $4 \mathrm{~mL}$ of distilled water. Then, $0.3 \mathrm{~mL}$ of $5 \% \mathrm{NaNO}_{2}$ solution was added and incubated for $5 \mathrm{~min}$. The addition of $0.3 \mathrm{~mL}$ of $10 \% \mathrm{AlCl}_{3}$ solution followed, and the mixture was allowed to stand for $6 \mathrm{~min}$. Next, $2 \mathrm{~mL}$ of $1 \mathrm{~mol} \mathrm{~L}-1 \mathrm{NaOH}$ solution was added, and the final volume was brought to $10 \mathrm{~mL}$ with double-distilled water. The mixture was allowed to stand for $15 \mathrm{~min}$, and absorbance was measured at $510 \mathrm{~nm}$. The concentration of total flavonoid content in the test samples was calculated from the calibration plot and expressed as $\mu \mathrm{g}$ quercetin equivalent $(\mathrm{QE}) / \mathrm{mg}$ of dried plant material.

\subsection{DPPH Activity Assay}

Antioxidant activity of the extract was measured using the scavenging effect of radicals on DPPH (2,2-diphenyl-1-picrylhydrazyl) [20]. To examine the antioxidant enzyme activity of mushroom extracts from the different treatment groups, the extracts were mixed homogenously with the DPPH reagent solution and incubated for $30 \mathrm{~min}$, in the dark, at room temperature. The absorbance spectra of the mixtures were measured using a spectrophotometer (Synergy HT, BioTek Instruments, Winooski, VT, USA) at $517 \mathrm{~nm}$. The following formula was used to calculate radical scavenging activity (\% inhibition):

$$
\% \text { Inhibition }=\left(\mathrm{A}_{\text {Blank }}-\mathrm{A}_{\text {Sample }}\right) / \mathrm{A}_{\text {Blank }} \times 100
$$

\subsection{Cell Culture}

Breast cancer cell lines MCF7 (ATCC ${ }^{\circledR}$ HTB-22 ${ }^{\mathrm{TM}}$ ) and MDA-MB231 (ATCC ${ }^{\circledR}$ HTB-26 ${ }^{\mathrm{TM}}$ ) were procured from American Type Culture Collection (Manassas, VA, USA). The normal breast epithelial cell line MCF10A (ATCC ${ }^{\circledR}$ CRL-10317 ${ }^{\mathrm{TM}}$ ) was obtained from Seoul National University, Seoul, Korea. MCF7 and MDA-MB231 cells were grown in DMEM medium (Welgene LM001-05, Gyeongsan-si, Korea) supplemented with $10 \%$ serum, penicillin, and streptomycin. MCF10A cells were cultured in 
MEGM medium (Lonza CC-3150). All cell lines were maintained in a humidified incubator with 5\% $\mathrm{CO}_{2}$ at $37^{\circ} \mathrm{C}$.

\subsection{Cytotoxicity of Extracts}

The cytotoxicity of mushroom extracts was determined using Alamar Blue dye (DAL1025, Thermo Fisher Scientific, Waltham, MA, USA). Briefly, $1 \times 10^{4}$ cells per well $(100 \mu \mathrm{L})$ were seeded in triplicate in 96-well cell culture plates. Each experimental set consisted of the control extract (untreated groups, $0 \mathrm{~s}$ ) and plasma-treated (30 and $60 \mathrm{~s}$ ) groups at different concentrations $(10,50,100,200,500$, and $\left.1000 \mu \mathrm{g} \mathrm{mL} \mathrm{m}^{-1}\right)$. Untreated cells served as a negative control for each group. Alamar Blue dye $(10 \% v / v$ in media) was added to each well, as described [21]. The fluorescence emission after dye conversion was measured using a $540 \mathrm{~nm}$ excitation and $595 \mathrm{~nm}$ emission in a BioTek microplate reader.

\subsection{Flow Cytometry Analysis}

To measure cell death induced by mushroom extract treatment, $2 \times 105$ cells were seeded in a $35 \mathrm{~mm}$ dish. Following $24 \mathrm{~h}$ of treatment, cells were washed, harvested, and stained with Annexin V-FITC and propidium iodide using a BD Pharmingen ${ }^{\mathrm{TM}}$ FITC Annexin V Apoptosis Detection Kit I (BD 556547; BD Biosciences, San Diego, CA, USA), according to the manufacturer's protocol. For cell cycle assessment, $2 \times 10^{5}$ cells were seeded in $35 \mathrm{~mm}$ dishes for treatment with extracts. The following day, cells were washed with cold $1 \times$ PBS containing $2 \%$ serum, fixed with $70 \%$ ethanol for $1 \mathrm{~h}$, centrifuged, and resuspended in PI staining solution ( $20 \mu \mathrm{g} \mathrm{mL}^{-1} \mathrm{PI}, 50 \mu \mathrm{g} \mathrm{mL}{ }^{-1}$ RNase A) for overnight incubation at $4{ }^{\circ} \mathrm{C}$. Cells were washed, centrifuged, and resuspended in $1 \times$ PBS before acquisition and analysis using the BD FACSVerse instrument. For ROS measurements, cells were cultured in $60 \mathrm{~mm}$ cell culture dishes and treated with mushroom extracts. Cells were harvested after $24 \mathrm{~h}$ and incubated with 2', 7'-dichlorodihydroflourescein diacetate (H2DCFDA) (\#D-399, Life Technologies, Invitrogen, Burlington, ON, Canada), followed by washing and resuspension with cold PBS, for immediate analysis using the BD FACSVerse instrument. For DNA damage determination, the total $\gamma-\mathrm{H} 2 \mathrm{AX}$ level was measurement using FACS analysis. Briefly, $2 \times 10^{5}$ cells were cultured in $35 \mathrm{~mm}$ dishes in triplicates. Following $24 \mathrm{~h}$ treatment, cells were harvested and stained with primary H2AX antibody (7631s, Cell Signaling, Danvers, MA, USA) and fluorescent secondary Alexafluor (A11009, Invitrogen, Burlington, ON, Canada) antibody for $45 \mathrm{~min}$, followed by acquisition and analysis with BD FACS verse.

\subsection{Primer Design and Quantitative Real-Time PCR}

To determine changes in gene expression, total RNA was extracted from untreated cells, as well as from cells treated with plasma-exposed mushroom extract, using Trizol reagents (RNAiso Plus, Takara, Shiga, Japan), according to the manufacturer's protocol. Template cDNA from $2 \mu \mathrm{g}$ of RNA was prepared using reverse transcription supermix (MMLV reverse transcriptase, RT buffer (500 mM Tris- $\mathrm{HCl} \mathrm{pH} 8.3,30 \mathrm{mM} \mathrm{MgCl}$, $100 \mathrm{mM} \mathrm{DTT}$, and $750 \mathrm{mM} \mathrm{KCl),} \mathrm{RNase} \mathrm{inhibitor,} \mathrm{and} \mathrm{dNTPs)} \mathrm{according}$ to the Enzynomics protocol. PCR reactions were carried out in an iCycler IQ real-time detection system (Bio-Rad laboratories, Hercules, CA, USA) using iQ SYBR Green Supermix (Bio-Rad). The primers used in this study are listed in Table 1. All primers were designed and purchased from DNA Macrogen, Seoul, Korea. 
Table 1. List of primer sequences used in this study.

\begin{tabular}{|c|c|c|}
\hline Gene Name & Sequence $\left(5^{\prime}-3^{\prime}\right)$ & Size (bp) \\
\hline ACTIN-forward & GGC ATC CTC ACC CTG AAG TA & \multirow{2}{*}{82} \\
\hline ACTIN-reverse & AGG TGT GGT GCC AGA TTT TC & \\
\hline BAX-forward & AAG AAG CTG AGC GAG TGT CTC & \multirow[b]{2}{*}{186} \\
\hline BAX-reverse & GCT GGC AAA GTA GAA AAG GGC & \\
\hline BCL2-forward & TTC TTT GAG TTC GGT GGG GTC & \multirow{2}{*}{208} \\
\hline BCL2-reverse & TCT TCA GAG ACA GCC AGG AGA & \\
\hline BCL-XL-forward & TCA GTG AGT GAG CAG GTG TT & \multirow{2}{*}{170} \\
\hline BCL-XL-reverse & GGC CTC AGT CCT GTT CTC TT & \\
\hline TP53-forward & GCC CСТ CСТ CAG CAT CTT ATC & \multirow{2}{*}{246} \\
\hline TP53-reverse & AAA GCT GTT CCG TCC CAG TAG & \\
\hline H2AX-forward & CAA CAA GAA GAC GCG AAT CA & \multirow[b]{2}{*}{223} \\
\hline $\mathrm{H} 2 \mathrm{AX}$-reverse & CGG GCC CTC TTA GTA CTC CT & \\
\hline Casp3-forward & ATG TCG ATG CAG CAA ACC TC & \multirow{2}{*}{173} \\
\hline Casp3-reverse & TCC TTC TTC ACC ATG GCT CA & \\
\hline Casp7-forward & AGA AGC TGT TAC CAC ACC CA & \multirow{2}{*}{185} \\
\hline Casp7-reverse & ACT CCA TCT CAG TCA GTG GC & \\
\hline Casp8-forward & CCC AAA TCA ACA AGA GCC TGC & \multirow{2}{*}{219} \\
\hline Casp8-reverse & TCA GAC AGT ATC CCC GAG GTT & \\
\hline CytC-forward & CAA CAC CTC TCA CAT CTT ACA GA & \multirow{2}{*}{185} \\
\hline CytC-reverse & GGC AAA AGC ACC ATT CCC AA & \\
\hline PUMA-forward & CCC ACC ACC ATC TCA GGA AA & \multirow[b]{2}{*}{185} \\
\hline PUMA-reverse & GTG GTC ACG TTT GGC TCA TT & \\
\hline
\end{tabular}

\subsection{Confocal Microscopy for DNA Damage Assessment}

Microscopic evaluations of DNA damage were carried out using DAPI and $\gamma-\mathrm{H} 2 \mathrm{AX}$ (BD Pharmingen, \#560447, San Diego, CA, USA) staining. Briefly, $2 \times 10^{5}$ cells were cultured on coverslips inside $35 \mathrm{~mm}$ dishes. After $24 \mathrm{~h}$ of treatment, cells were washed with 1X cold PBS, fixed with $4 \%$ paraformaldehyde (30 min at room temperature), followed by staining with H2AX antibody, according to the manufacturer's protocol. Then, the cells were assessed by confocal microscopy for DNA and cellular damage.

\subsection{Statistical Analysis}

Results are expressed as the means \pm SD of triplicates from three independent experiments. Significant differences between groups were analyzed using Student's $t$-tests. Multiple group comparisons were made using one-way ANOVA test. Significance was considered to be ${ }^{*} p<0.05$, ** $p<0.01$, and ${ }^{* * *} p<0.001$.

\section{Results}

\subsection{Detection of RONS in Medium Exposed to Plasma}

Since plasma generates various reactive species in medium, we assayed $\mathrm{H}_{2} \mathrm{O}_{2}$ and $\mathrm{NO}_{x}$ assays using commercially available kits. Concentrations of $\mathrm{H}_{2} \mathrm{O}_{2}$ and $\mathrm{NO}_{x}$ time-dependently increased after plasma exposure (Figure 1E,F). An increased concentration of RONS eventually creates the oxidative stress in biological samples.

\subsection{Phytochemical and Antioxidant Activities of Extracts Derived from Plasma-Exposed Mushrooms}

Total phenolic content and total flavonoid content of the mushroom fruiting body extract were calculated from calibration curves. Phenolic compounds have redox properties that allow them to act as antioxidants [22]. Flavonoids, including flavones, flavonols, and condensed tannins, are plant secondary metabolites, the antioxidant activity of which depends on the presence of free $\mathrm{OH}$ groups, especially 
3-OH. These flavonoids exhibit antioxidant activity in vitro and act as antioxidants in vivo [23]. To determine whether plasma could affect these biological components, we measured the levels of phenols and flavonoids in untreated/plasma-treated mushroom-derived extracts using Folin-Ciocalteu and aluminum chloride colorimetric methods, respectively. Here, the $30 \mathrm{~s}$ plasma-treated mushroom groups produced the highest levels of phenolic and flavonoid compounds as compared with the $60 \mathrm{~s}$ and $0 \mathrm{~s}$ treatment groups (Figure 2B,C). These findings suggest that plasma exposure for $30 \mathrm{~s}$ increases phenol and flavonoid content in the mushroom extracts, which might possess antioxidant properties. Therefore, we assayed DPPH radical scavenging that relies on color changes due to free radicals. Decreasing absorption values are directly proportional to the amount of produced DPPH [24]. The DPPH inhibition activity was notably higher in the samples from the $30 \mathrm{~s}$ groups than in those from the $60 \mathrm{~s}$ and $0 \mathrm{~s}$ groups. These results were consistent with the increased phenol and flavonoid contents under similar exposure conditions (Figure 2D). These results suggest that plasma exposure can improve phytoconstituent levels and antioxidant properties in mushroom extracts.

\subsection{Analysis of Active Constituents by FTIR and UV-Vis}

For analyzing the types of functional groups present in plant extracts, FTIR spectroscopy is an important characterization that provides the structural information in plants. In this experiment, dried powders of mushroom extracts were used. The $900-4000 \mathrm{~cm}^{-1}$ complete FTIR spectra are shown in Figure $3 \mathrm{~A}$, denoting several functional groups that are normally observed in mushrooms, such as broad bands at $3300 \mathrm{~cm}^{-1}$ of $-\mathrm{OH}$, and at $1640 \mathrm{~cm}^{-1}$ of $\mathrm{C}=\mathrm{C}$ stretching, respectively. The $-\mathrm{OH}$ functional group indicates phenol. Figure 3B shows the magnified spectra in the $900-1500 \mathrm{~cm}^{-1}$ range. New functional groups in this range were generated after exposure to plasma. For instance, the band at $1421 \mathrm{~cm}^{-1}$ can be attributed to -OH bending, while the bands at $1090 \mathrm{~cm}^{-1}$ and $1039 \mathrm{~cm}^{-1}$ can be attributed to $\mathrm{C}-\mathrm{O}$ stretching.
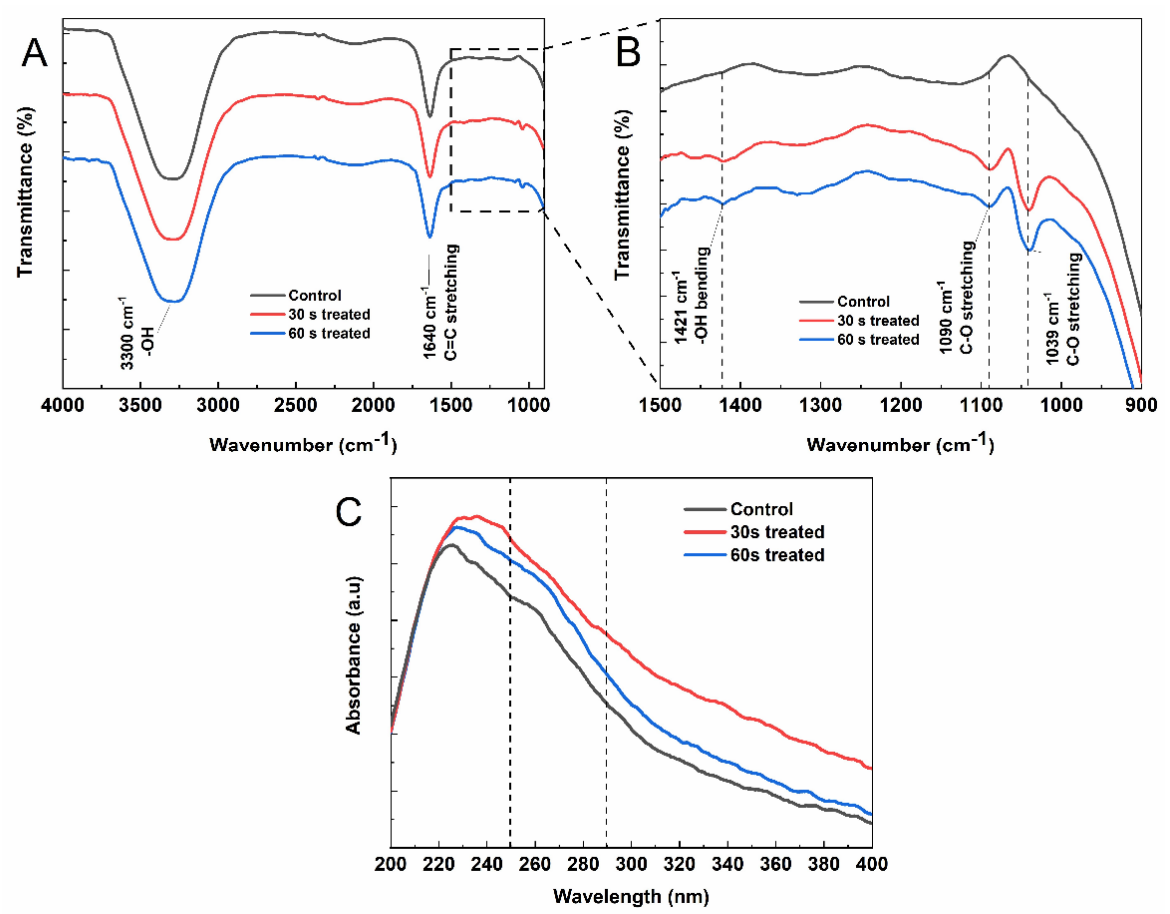

Figure 3. Fourier transform infrared spectra and UV-Vis analysis of extracts of nonthermal gas plasma-treated mushroom-derived extracts. Fourier transform infrared spectra of F. velutipes extract (A) 900-4000 $\mathrm{cm}^{-1}$ and (B) $900-1500 \mathrm{~cm}^{-1}$. Black line, control (0 s not exposed to plasma); red line, exposed to plasma for $30 \mathrm{~s}$; blue line, exposed to plasma for $60 \mathrm{~s}$; (C) UV-Vis absorption spectra of F. velutipes extracts. Black line, control ( $0 \mathrm{~s}$ not exposed to plasma); red line, exposed to plasma for $30 \mathrm{~s}$; and blue line, exposed to plasma for $60 \mathrm{~s}$. 
We also analyzed the extracts using UV-Vis spectroscopy. The color of chemicals directly affects absorption in visible and ultraviolet ranges. Figure $3 \mathrm{C}$ shows absorption peaks mainly in the region of $230-400 \mathrm{~nm}$ in the UV-Vis spectra of all three extracts. This region is closely associated antioxidant components such as phenols, flavonoids, and aromatic compounds [25]. Natural polyphenols and flavonoid components have absorbance maxima in the ranges of 260-350 [25] and 280-350 [26] nm, respectively. Although all samples produced peaks in these regions, absorbance was higher for the 30 and $60 \mathrm{~s} \mathrm{samples} \mathrm{as} \mathrm{compared} \mathrm{with} \mathrm{control} \mathrm{samples} \mathrm{at} \mathrm{the} \mathrm{same} \mathrm{wavelength.} \mathrm{The} \mathrm{peak} \mathrm{was}$ more obvious for the $30 \mathrm{~s}$ than the $60 \mathrm{~s}$ group, which was consistent with results obtained from the phytochemical analysis.

\subsection{Antiproliferative Activity of Plasma-Treated Mushroom-Derived Extracts in Breast Cancer Cells}

We investigated the antiproliferative activity of 1000, 500, 200, 100, 50, and $10 \mu \mathrm{g} \mathrm{mL}^{-1}$ mushroom extracts against the breast cancer cell lines, MCF7 and MDA-MB231. Various concentrations were tested on the three plasma treatment groups ( 0 (control), 30, and $60 \mathrm{~s}$ ) at $24 \mathrm{~h}$ post-incubation, using Alamar Blue assays of emitted fluorescence. Extracts derived from the 30 and $60 \mathrm{~s}$ groups concentration dependently inhibited the growth of both cells (Figure $4 \mathrm{~A}, \mathrm{~B}$ ). However, the effect of the $30 \mathrm{~s}$ group was more prominent in MCF7 than in MDA-MB231 cells. Growth inhibition of both cell lines was similar in the case of the extracts from the 60 s group. The control extracts had no inhibitory effect on the growth of breast cancer cells, at any of the tested concentrations. We compared toxicity by assessing MCF10A normal mammary epithelial cell viability using the same extracts (i.e., 0,30 , and $60 \mathrm{~s}$ ) and conditions. The MCF10A cells remained unaffected by all three extracts at all tested concentrations (Figure 4C). These results indicated that extracts derived from plasma-treated mushrooms can inhibit the growth of breast cancer cells in vitro (Supplementary Figure S1).

\subsection{Extracts Derived from Plasma-Treated Mushrooms Induce Cancer Cell Death due to Cell Cycle Arrest}

The results of the Alamar Blue activity assay showed that the viability of cancer cells concentration dependently decreased when incubated with the extracts of plasma-exposed mushrooms. Annexin-V/PI provides a sensitive approach for determining cellular apoptosis, as well as necrotic or late apoptotic cells. Thus, we further assessed cell death in breast cancer cells, at extract concentrations of 50 (low) and 200 (high) $\mu \mathrm{g} \mathrm{mL}^{-1}$, using flow cytometry. The Annexin-V/PI findings revealed that the plasma-treated mushroom-derived extracts for 30 and $60 \mathrm{~s}$ caused the maximum death of MCF7 cells as compared with the controls (Figure 5A,B). The extracts exposed to plasma for 30 and $60 \mathrm{~s}$ (at a concentration of $200 \mu \mathrm{g} \mathrm{mL}^{-1}$ ) resulted in $30.25 \%$ (double-positive cells) and $20.65 \%$ cell death, respectively. The control extracts were relatively toxic toward MCF7 cancer cells $(14.93 \%$ at $50 \mu \mathrm{g}$ $\mathrm{mL}^{-1}$ and $12.13 \%$ at $200 \mu \mathrm{g} \mathrm{mL}^{-1}$ ), but minimally toxic toward MCF10A cells (5.77\% at $50 \mu \mathrm{g} \mathrm{mL}^{-1}$ and $4.36 \%$ at $200 \mu \mathrm{g} \mathrm{mL}^{-1}$, Figure 5C,D). The findings were similar in MDA-MB231 cancer cells but were more prominent in MCF7 cells (Supplementary Figure S2). 
A

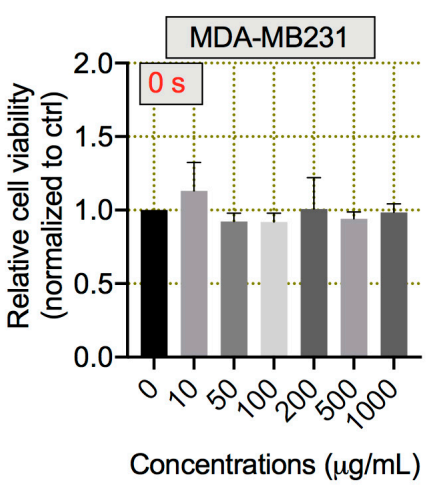

B

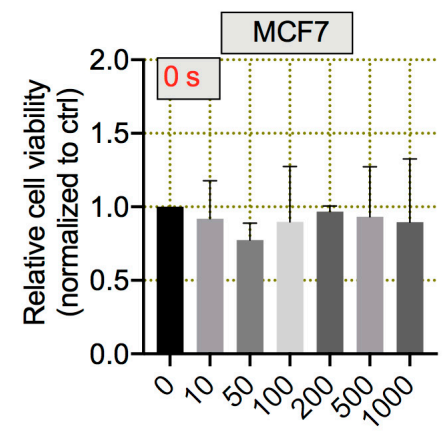

C

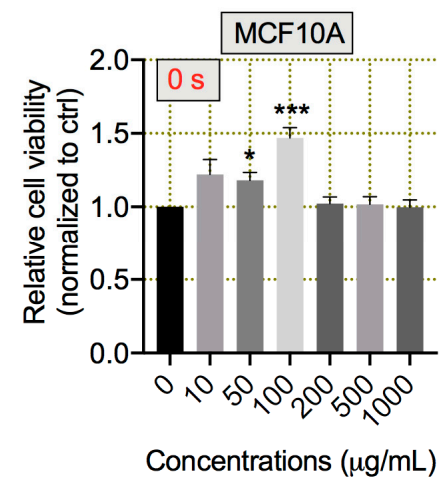

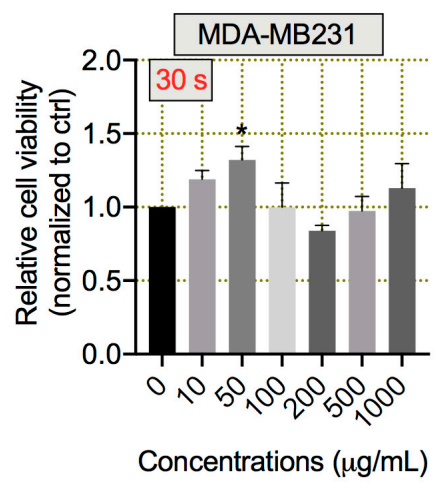
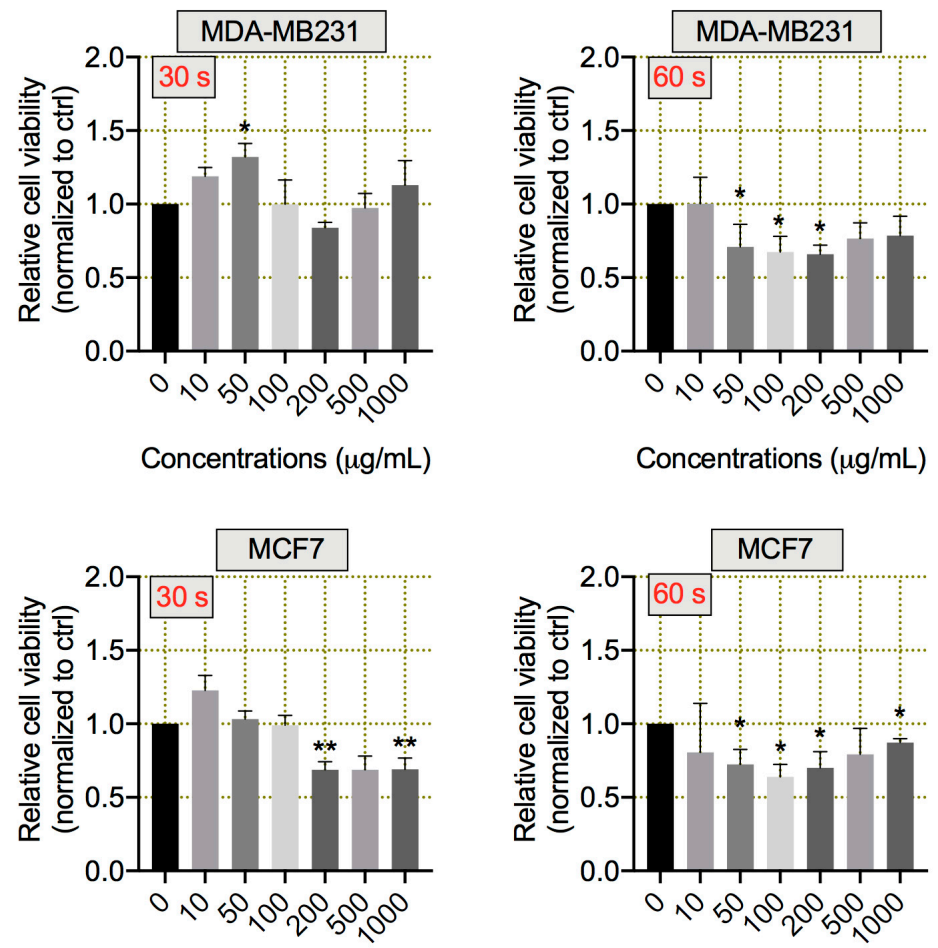

Concentrations $(\mu \mathrm{g} / \mathrm{mL})$

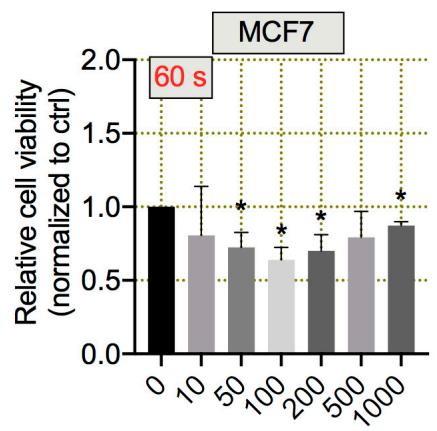

Concentrations $(\mu \mathrm{g} / \mathrm{mL})$

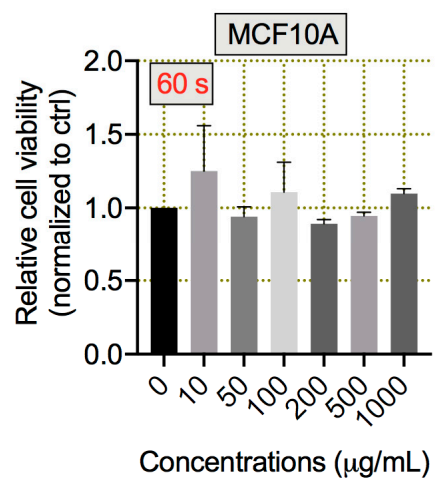

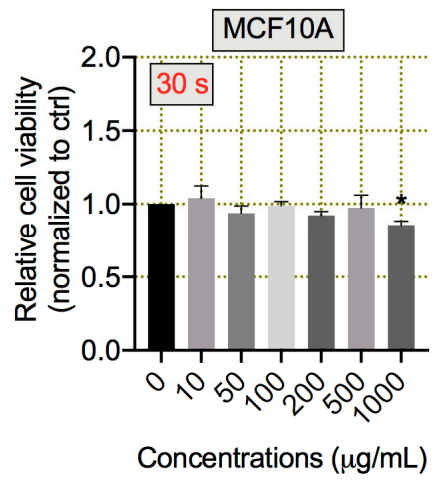

Figure 4. Extracts derived from plasma-treated mushrooms are cytotoxic to breast cancer cells. (A-C) Results of Alamar Blue assays performed using MDA-MB231, MCF7 cancer, and MCF10A normal cells incubated for $24 \mathrm{~h}$ with $0,10,50,100,200,500$, and $1000 \mu \mathrm{g} \mathrm{mL} \mathrm{m}^{-1}$ of extracts derived from plasma-treated mushrooms for $30 \mathrm{~s}, 60 \mathrm{~s}$, or left unexposed ( $0 \mathrm{~s}$, control). ${ }^{*} p<0.05$, ** $p<0.01$, and ${ }^{* *} p<0.001$. Untreated sample was used as a control in all tested plant extracts groups for normalization. 
A

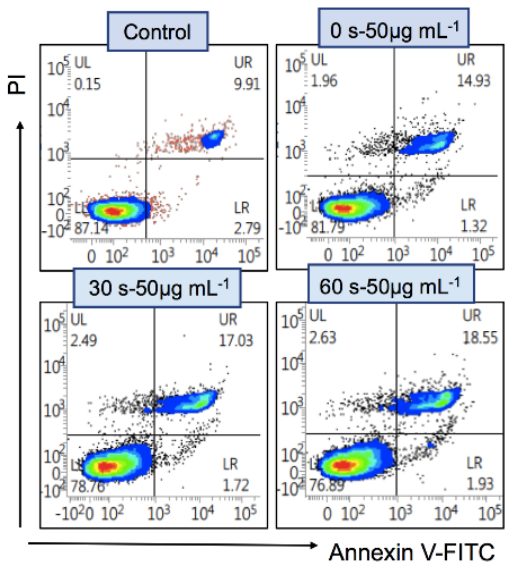

C

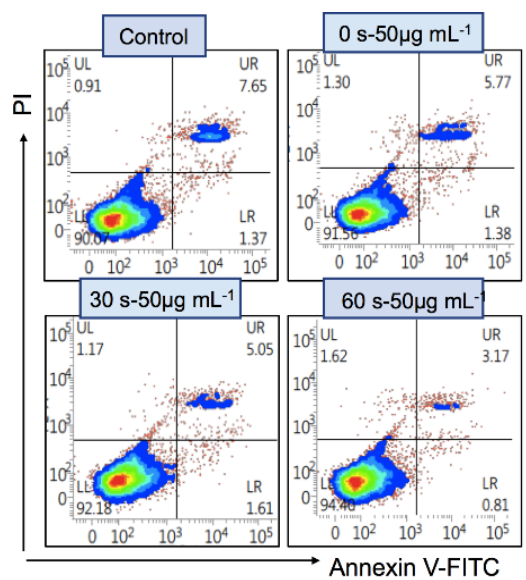

B

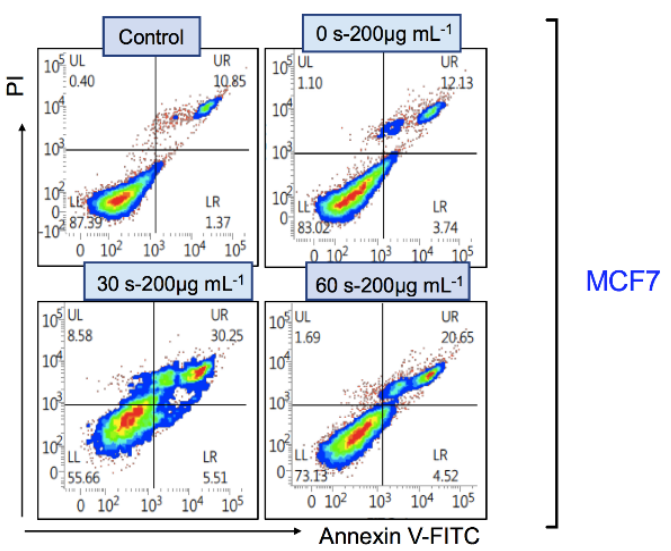

D

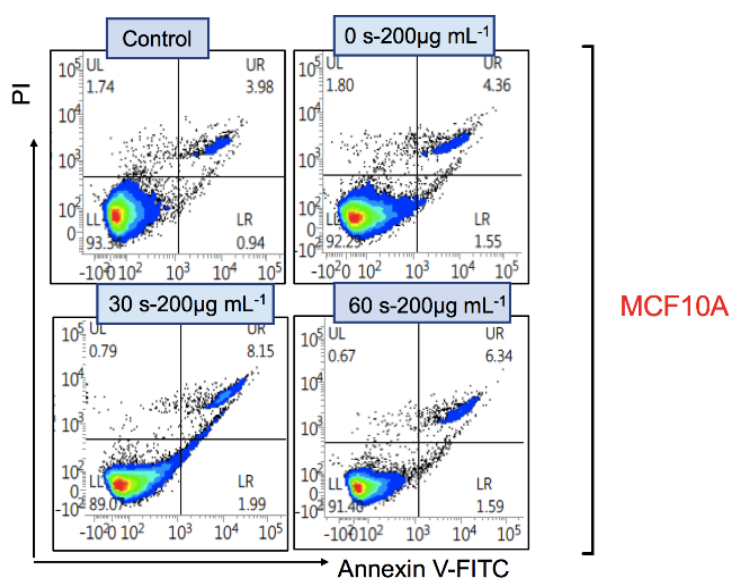

Figure 5. Plasma-treated mushroom-derived extracts stimulate apoptotic cell death in breast cancer cells. (A-D) Cell death analysis in MCF7 breast cancer and MCF10A normal mammary epithelial cells treated with extracts prepared from 30 and $60 \mathrm{~s}$ plasma-treated, and untreated $(0 \mathrm{~s})$ mushrooms at 50 and $200 \mu \mathrm{g} \mathrm{mL}^{-1}$ after $24 \mathrm{~h}$ post-incubation using Annexin-V/PI staining.

Many natural products inhibit cell proliferation and induce death by inducing arrest at different phases of the cell cycle [27]. Cell cycle arrest (G1 phase) and apoptosis are different means of cellular growth arrest that lead to the failure of a cell to move into the $S$ phase. Therefore, we analyzed MCF7 cancer cell cycles, after incubation with 50 and $200 \mu \mathrm{g} \mathrm{mL} \mathrm{L}^{-1}$ of extracts. Flow cytometry results revealed an arrest in the G2/M phase of MCF7 cells by PI/RNase A staining with plasma-treated mushroom-derived extracts, while S-phase was also affected at $30 \mathrm{~s}$ plasma-treated mushroom-derived extract at $200 \mu \mathrm{g} \mathrm{mL}{ }^{-1}$. The effects were similar in MCF7 cells incubated with control extract (Figure 6A-C), indicating that the untreated mushrooms contain several phenolic compounds that affect the cell cycle, rather than promoting proliferation in cancer cells. However, this requires further investigation. The results indicated that the inhibitory effects induced by the extracts on breast cancer cell growth were due to the incidence of cell death associated with cell cycle arrest. 
A

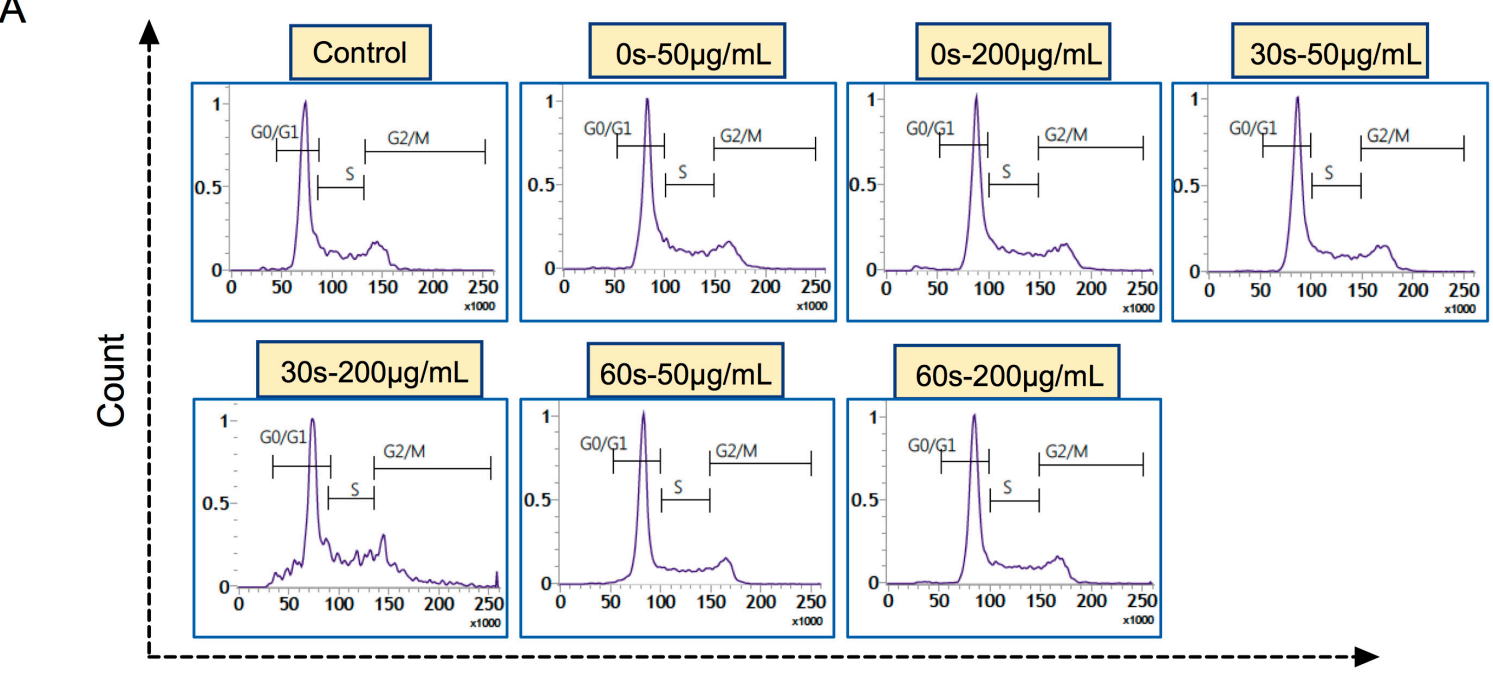

B
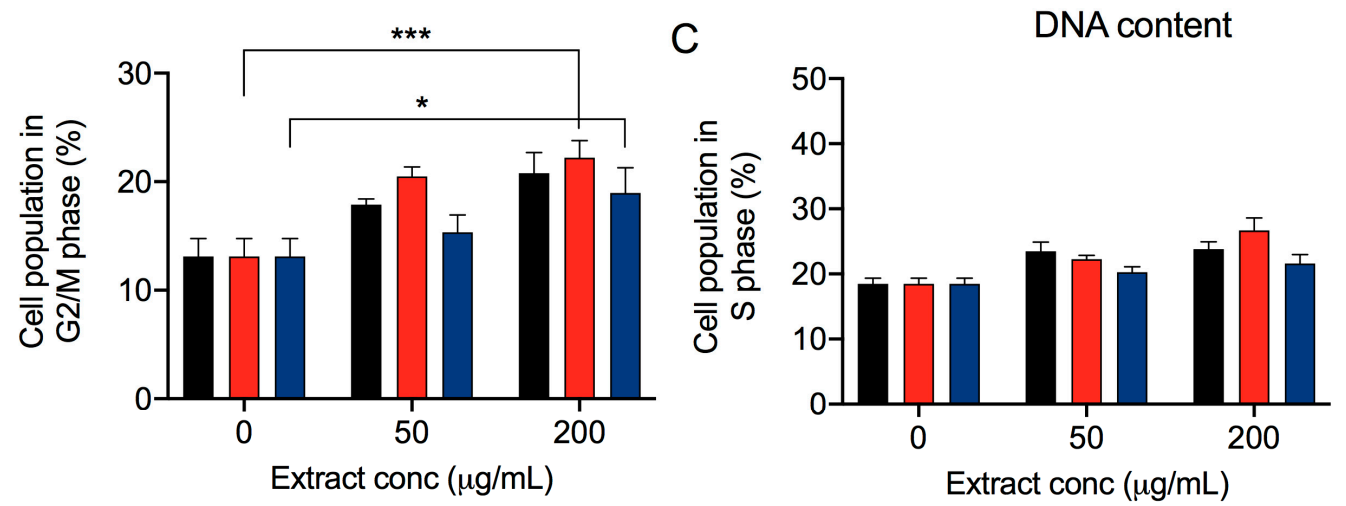

0 s plasma treatment $\square 30$ s plasma treatment

60 s plasma treatment

Figure 6. Cell cycle arrest is associated with cancer cell death. (A-C) Flow cytometry analysis of MCF7 breast cancer cells treated with extracts prepared from $0 \mathrm{~s}$ (untreated), 30 and $60 \mathrm{~s}$ plasma-treated mushrooms at 50 and $200 \mu \mathrm{g} \mathrm{mL} \mathrm{m}^{-1}$ using PI/RNase A, after $24 \mathrm{~h}$ post-incubation. Representative graph shows percentage of cell population in G2/M and S phase. ${ }^{*} p<0.05$, and ${ }^{* * *} p<0.001$.

\subsection{Plasma-Exposed Mushroom-Derived Extracts Induced ROS Generation for Apoptosis}

Several natural compounds from plant extracts can increase intracellular ROS levels as primary mechanisms to stimulate cancer cell death $[28,29]$. Consequently, phytocomponents released from plasma-treated mushrooms might increase intracellular ROS levels as a precursor to cell death. We measured ROS levels in MCF7 cancer and MCF10A normal cells using H2DCFDA, which emits green fluorescence in the presence of ROS upon oxidation. Figure 7A shows that intracellular ROS levels significantly increased in MCF7 cells incubated with 50 and $200 \mu \mathrm{g} \mathrm{mL}^{-1}$ extracts derived from plasma-treated mushrooms using flow cytometry. The untreated controls also induced ROS induction at $200 \mu \mathrm{g} \mathrm{mL}^{-1}$ of extract, which was consistent with the cell cycle data (Figure 7B). Levels of ROS were slightly affected in MCF10A cells subjected to similar treatments (Figure 7C,D). Microscopy analysis further confirmed the induction of oxidative stress in MCF7 cells incubated with extracts visualized as increased green fluorescence (Figure 7E). 
A

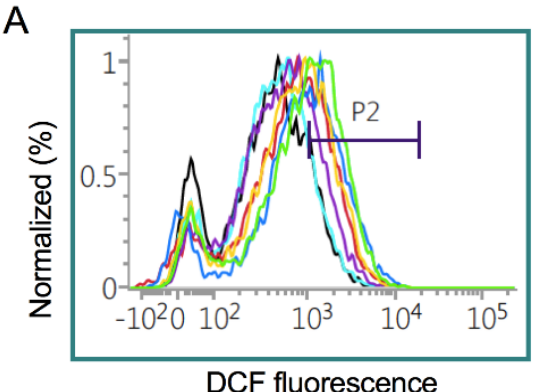

B

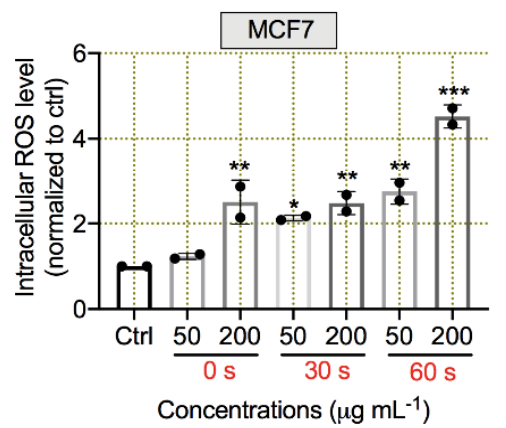

C

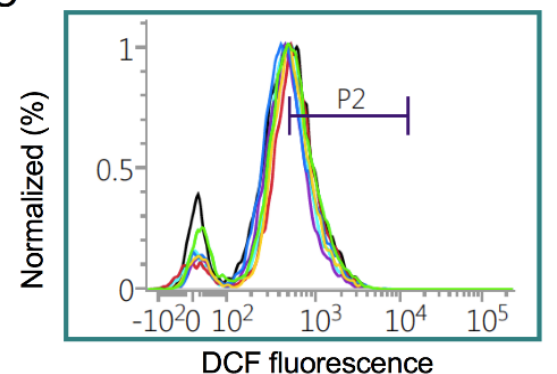

D

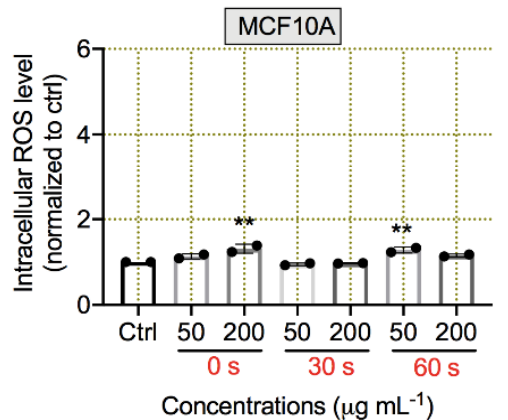

E

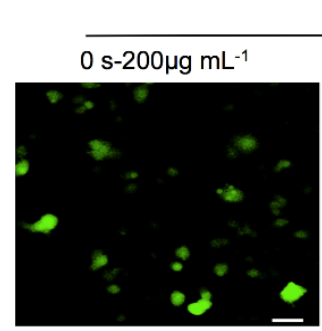

MCF7

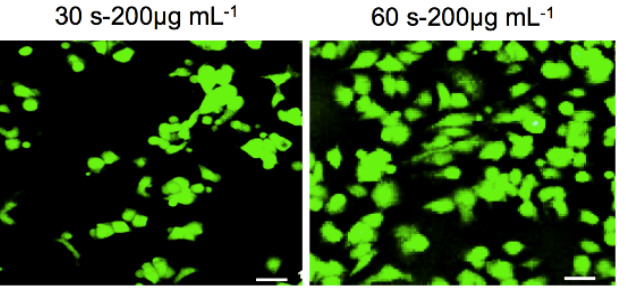

Figure 7. Plasma-treated mushroom-derived extracts induced intracellular oxidative stress. (A-D) Flow cytometric detection of intracellular ROS in MCF7 breast cancer and MCF10A normal cells treated with extracts prepared from $0 \mathrm{~s}$ (untreated), 30 and $60 \mathrm{~s}$ plasma-treated $(0 \mathrm{~s})$ mushrooms, after $24 \mathrm{~h}$ post-incubation at 50 and $200 \mu \mathrm{g} \mathrm{mL}{ }^{-1}$ using fluorescent H2DCFDA dye, respectively; (E) Microscopic images of ROS detection in MCF7 cells treated in similar conditions as above. Untreated sample (no extract) was used as control for normalization. ${ }^{*} p<0.05,{ }^{* *} p<0.01$, and ${ }^{* * *} p<0.001$.

These findings show that ROS induction can influence cancer cell apoptosis, which is regulated by several signaling pathways and related molecules. Therefore, to verify the ability of the mushroom extracts to induce breast cancer cell apoptosis, we measured the expression of apoptosis-related gene markers in MCF7 cells under all three treatment groups (0, 30, and $60 \mathrm{~s})$ at a $200 \mu \mathrm{g} \mathrm{mL}^{-1}$ extract concentration. The expression of proapoptotic BAX, p53, Puma, CytC, Casp3, Casp7, and Casp 8 genes were upregulated in the 30 and 60 s groups, whereas the antiapoptotic $B c l-x L$ gene expression was not significantly altered as compared with the controls. Expression of the Bcl2 gene was increased in the 30 and $60 \mathrm{~s}$ groups. This was notable because Bcl2 belongs to the Bcl-2 family of proteins that regulate apoptotic cell death, either by inhibiting (antiapoptotic $B c l-x L, M c l-1, B c l-w$, and A-1) or inducing (proapoptotic Bax, Bik, Bak, and Bok) apoptosis [30,31]. These effects were more prominent in MCF7 breast cancer cells incubated with $30 \mathrm{~s}$ extracts. We also found that $H 2 A X$ expression increased, indicating double-strand breaks in the DNA of MCF7 cells incubated with 30 and 60 s extracts (Figure 8A-J). These results were further confirmed by immunofluorescence staining, which revealed $\gamma \mathrm{H} 2 \mathrm{AX}$ foci formation in MCF7 cells treated with 30 and 60 s extracts $\left(200 \mu \mathrm{g} \mathrm{mL}^{-1}\right)$ (Figure 9). To further confirm whether this induction of $\gamma \mathrm{H} 2 \mathrm{AX}$ was due to generally increased levels of $\mathrm{H} 2 \mathrm{AX}$, we measured total levels of $\gamma \mathrm{H} 2 \mathrm{AX}$. The levels of $\gamma \mathrm{H} 2 \mathrm{AX}$ did not considerably change in the cells incubated with 30 and $60 \mathrm{~s}$ extracts $\left(200 \mu \mathrm{g} \mathrm{mL}^{-1}\right)$ as compared with controls (Supplementary Figure S3). 
A

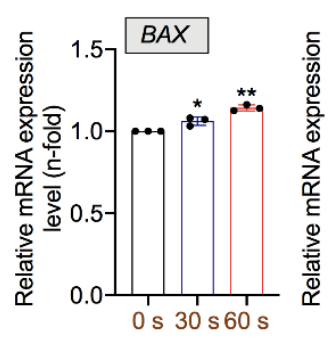

Plasma exposure time

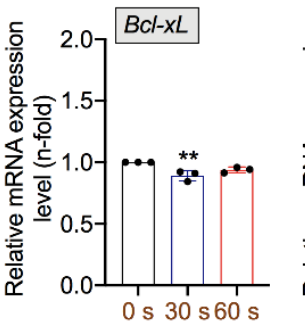

Plasma exposure time
C

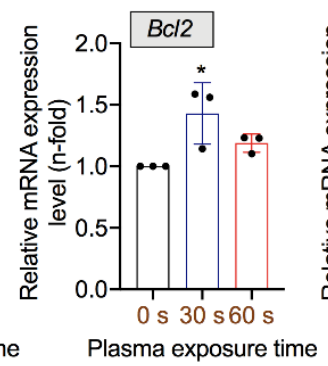

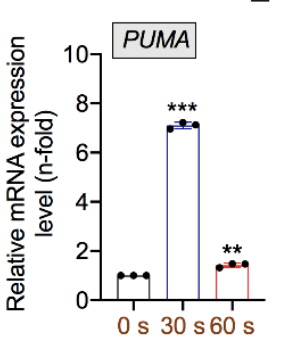

Plasma exposure time
E

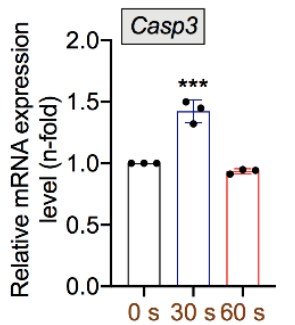

Plasma exposure time

Mushroom extract concentration (200 $\left.\mu \mathrm{g} \mathrm{mL}^{-1}\right)$

F

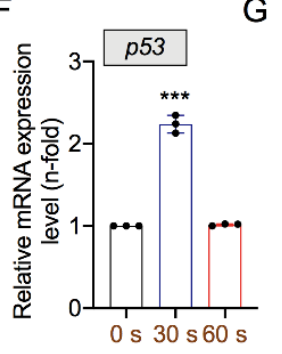

Plasma exposure time

G

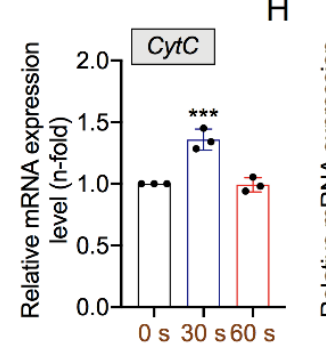

Plasma exposure time

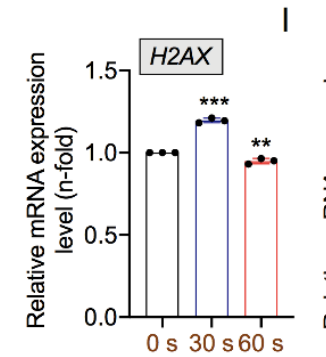

Plasma exposure time

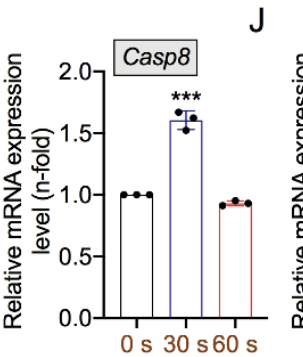

Plasma exposure time

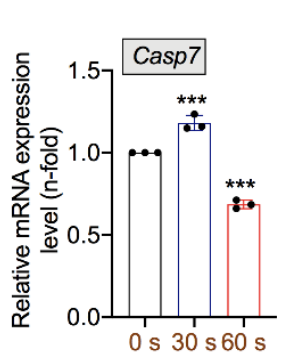

Plasma exposure time

Mushrom extract concentration $\left(200 \mu \mathrm{g} \mathrm{mL}^{-1}\right)$

Figure 8. Induction of cell death markers by plasma-treated mushroom-derived extracts. (A-J) Quantification of mRNA expression of BAX, Bcl-xL, BCl2, PUMA, Casp3, p53, CytC, H2AX, Casp8, and Casp7 apoptosis-related markers, respectively in MCF7 cells treated at $200 \mu \mathrm{g} \mathrm{mL}$ concentration. ${ }^{*} p<0.05,{ }^{* *} p<0.01$, and ${ }^{* * *} p<0.001$.

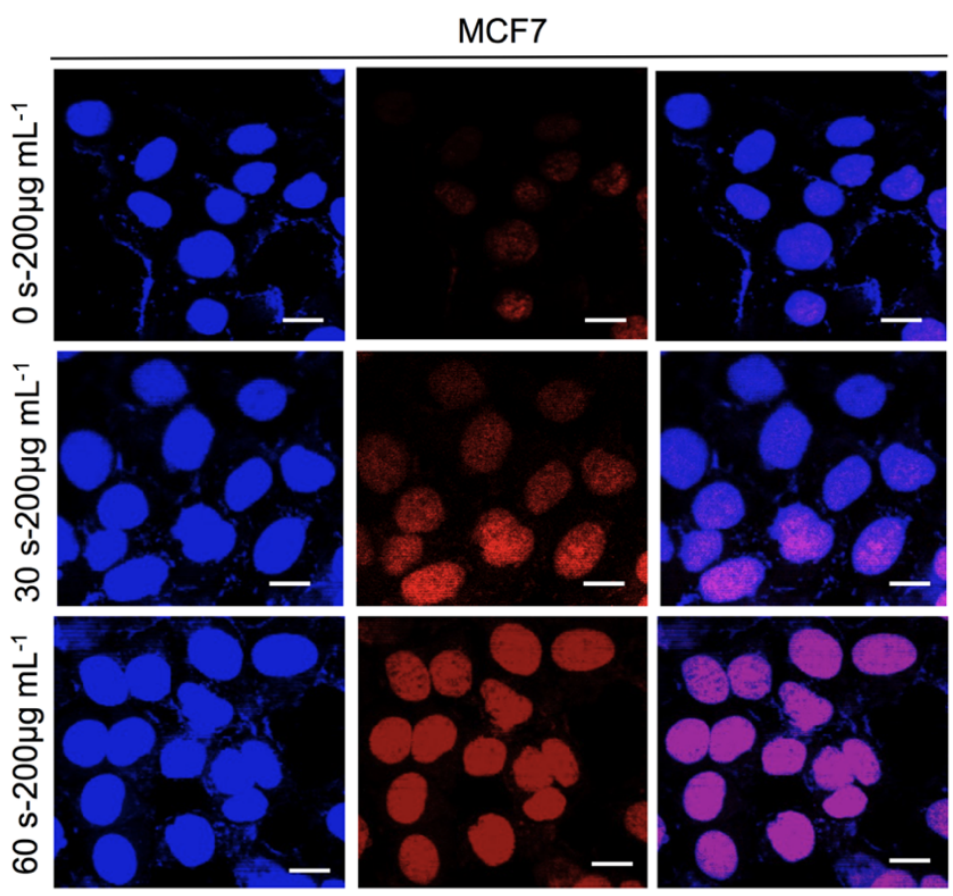

DAPI/H2AX

Figure 9. Plasma-treated mushroom-derived extracts provoke DNA damage in breast cancer cells. Quantification of H2AX foci formation in MCF7 cells by immunofluorescence staining treated as indicated. Scale bar, $20 \mu \mathrm{m}$. 


\section{Discussion}

Natural products, such as functional foods, have gained popularity as they provide alternatives to conventional cancer therapies, which are often accompanied by side effects and drug resistance. Mushrooms are rich in phytometabolic and bioactive constituents, and thus comprise an excellent alternative therapy that has health-promoting and tumor preventive effects [32]. Possible roles of various mushroom species in cancer treatment have been investigated [33,34], while others involving the optimization and improvisation of their constituents have already been directed towards anticancer therapeutics. In this regard, both direct and indirect treatment with NTP increases the yield and quality of plants including mushrooms, and improves other aspects of agriculture $[35,36]$. Here, we applied an air plasma jet for 30 and $60 \mathrm{~s}$ from an optimized device to enhance the yield and properties of $F$. velutipes, and then assessed characteristics and amounts of metabolic constituents such as phenols and flavonoids determined by FTIR and UV-Vis. Higher peak intensities in the UV-Vis spectra of extracts of plasma-treated mushrooms, indicated higher concentrations of constituents. Higher levels of total phenols, flavonoids, and antioxidant activities indicated that plasma enhanced the properties of mushroom extracts and might further improve their functions or applications such as cancer cell attenuation.

Natural products exhibit anticancer activity primarily via selective cytotoxicity toward cancer cells. The cell viability results indicated that the mushroom extracts could selectively affect the metabolic growth of cancer cells at specific doses, while normal mammary breast cells remained largely unharmed. Furthermore, this effect was significantly higher in MCF-7s than in MDA-MB-231 breast cancer cells. Water extracts of $F$. velutipes can inhibit both MCF-7 and MDA-MB-231 cells at different $\mathrm{IC}_{50}$ doses [13]. Water extracts of $F$. velutipes decrease the anticancer activity more prominently in MDA-MB-231 than MCF7 cells. However, we found that ethanol extracts of were highly cytotoxic to MCF-7 cancer cells. This might have been due to extract solvents differently affecting cancer cell subtypes. Differences in intrinsic molecular signaling patterns within subtypes of cancer and susceptibility towards certain bioactive compounds might also be involved [37]. Further investigation should provide more clarity into this aspect. We also found that reduced cell viability was associated with cell death and changes in the cell cycle. Consistent with these findings, more MCF7 than normal cells died, indicating that the mushroom extract effectively induced cell death in breast cancer as compared with normal mammary cells. The Annexin-V/PI analysis revealed that mushroom extracts prepared from plasma-treated mushrooms could induce cell death by apoptosis (Figure 5), due to changes in cell death markers. Furthermore, apoptotic cell death was associated with cell cycle arrest, as MCF7 cells were induced into the G2/M phase, while the S-phase also seemed to be affected by the $30 \mathrm{~s}$ extract $\left(200 \mu \mathrm{g} \mathrm{mL}^{-1}\right)$ in MCF7 cells (Figure 6). At similar concentrations, control (untreated) groups also had the intrinsic ability to alter cell cycle phases.

Several mushrooms contain high amounts of antioxidants such as polyphenol, and vital compounds that exert anticancer effects that might be realized through mechanisms similar to those of some drugs, for instance, Nrf2 inhibitors. Being rich in antioxidants, extracts of mushrooms can prevent tissue damage and apoptosis by scavenging ROS [38]. However, some mushroom extracts can induce ROS and subsequent apoptosis as anticancer effects [39]. We found that ROS levels were dose-dependently enhanced in groups incubated with mushroom extracts. Natural product-derived inhibitors of key pathways can induce ROS activity that can result in cell death [40-42]. However, cytotoxicity was maximal in the cells incubated with 30 s extracts, indicating ROS independent mechanisms. Apoptosis can be activated caspase-dependently without increasing ROS levels in cells [43]. Mushrooms are natural product with various metabolic constituents that can act as antioxidants and pro-oxidants depending on cellular milieu with increased ROS levels, which can also be a mechanism underlying cancer cell death [44]. Increased oxidative stress positively correlates with cell death by apoptosis and DNA damage [39]. Moreover, extracts from other mushroom species can alter the expression of apoptotic and DNA repair genes [45]. Consistent with these findings, our extracts of mushrooms exposed to plasma also significantly induced proapoptotic genes without affecting antiapoptotic gene 
expression. Furthermore, the upregulation of genes associated with DNA damage were upregulated, which might further promote apoptosis in cancer cells. In particular, extracts derived from mushrooms exposed to plasma for $30 \mathrm{~s}$ were relatively better at reducing cell viability (Figure 4), apoptosis (Figure 5), and at altering the expression of cell death-related genes. (Figure 8). Conversely, the $60 \mathrm{~s}$ plasma-treated mushroom-derived extracts were better at increasing ROS levels (Figure 7) and DNA damage (Figure 9). Therefore, we postulate that exposure to plasma can enhance the active properties and yield of mushroom constituents that could be useful for suppressing cancer cell growth. The mechanism of anticancer activity in extracts of plasma-treated mushrooms is primarily through the increased expression of apoptotic genes and DNA damage that results in the death of cancer cells.

\section{Conclusions}

In this study, we attempted to determine the anticancer activity of enoki mushrooms grown under plasma treatment against malignant breast cancer cells. To establish the role of plasma treatment on the enhancement of anticancer activity, we produced extracts from both plasma-treated and untreated mushrooms to evaluate their effects on breast cancer cells using various assays. Treating cancer cells with extracts of mushroom could be improved by exposing mushrooms to plasma. The $30 \mathrm{~s}$ extracts exerted more prominent effects on cancer cell death and induced apoptotic cell death markers. Further studies of the mechanisms related to this activity are required for validation. The anticancer potential of specific mechanisms of extracts from various mushroom species exposed to plasma should also be evaluated in future studies.

Supplementary Materials: The following are available online at http://www.mdpi.com/2076-3417/10/23/8395/s1, Figure S1: Plasma-treatment stimulates cytotoxicity of mushroom derived extracts against breast cancer cells, Figure S2: Plasma treatment improves effect of mushroom derived extracts on apoptotic cancer cell death, Figure S3: Levels of H2AX total protein does not alter in plasma-treated mushroom derived extracts exposed breast cancer cells.

Author Contributions: Conceptualization, S.M., N.K., and N.K.K.; methodology, S.M., P.B., N.K., R.W., S.B., and L.N.N.; software, N.K., S.B., and R.W.; validation, N.K.K.; formal analysis, S.M., P.B., N.K., and L.N.N.; investigation, S.M., P.B., N.K., and N.K.K.; writing-original draft preparation S.M., P.B., N.K., and N.K.K.; writing-review and editing, N.K., R.W., S.B., N.K.K., and E.H.C.; supervision, N.K.K., and E.H.C. All authors have read and agreed to the published version of the manuscript.

Funding: This study was supported by the National Research Foundation (NRF) of Korea, funded by the Korean government (NRF-2016K1A4A3914113), MSIT (Ministry of Science and ICT), Korea under the ITRC (Information Technology Research Center) support program (IITP-2020-0-01846) supervised by the IITP (Institute of Information \& Communications Technology Planning \& Evaluation), and by Kwangwoon University and the University of Suwon in 2020.

Conflicts of Interest: The authors declare no conflict of interest.

\section{References}

1. Mitra, S.; Dash, R. Natural Products for the Management and Prevention of Breast Cancer. Evid. Based Complement. Altern. Med. 2018, 2018, 8324696. [CrossRef] [PubMed]

2. Wu, M.; Luo, X.; Xu, X.; Wei, W.; Yu, M.; Jiang, N.; Ye, L.; Yang, Z.; Fei, X. Antioxidant and immunomodulatory activities of a polysaccharide from Flammulina velutipes. J. Tradit. Chin. Med. 2014, 34, 733-740. [CrossRef]

3. Ukaegbu, C.I.; Shah, S.R.; Hazrulrizawati, A.H.; Alara, O.R. Acetone extract of Flammulina velutipes caps: A promising source of antioxidant and anticancer agents. Beni-Suef Univ. J. Basic Appl. Sci. 2018, 7, 675-682. [CrossRef]

4. Scholtz, V.; Šerá, B.; Khun, J.; Šerý, M.; Julák, J. Effects of Nonthermal Plasma on Wheat Grains and Products. J. Food Qual. 2019, 2019, 7917825. [CrossRef]

5. Dobrin, D.; Magureanu, M.; Mandache, N.B.; Ionita, M.-D. The effect of non-thermal plasma treatment on wheat germination and early growth. Innov. Food Sci. Emerg. 2015, 29, 255-260. [CrossRef]

6. Bourke, P.; Ziuzina, D.; Boehm, D.; Cullen, P.J.; Keener, K. The potential of cold plasma for safe and sustainable food production. Trends Biotechnol. 2018, 36, 615-626. [CrossRef]

7. Neyts, E.C. Plasma-Surface Interactions in Plasma Catalysis. Plasma Chem. 2016, 36, 185-212. [CrossRef] 
8. Hirst, A.M.; Frame, F.M.; Arya, M.; Maitland, N.J.; O'Connell, D. Low temperature plasmas as emerging cancer therapeutics: The state of play and thoughts for the future. Tumor Biol. 2016, 37, 7021-7031. [CrossRef]

9. Laroussi, M. Plasma Medicine: A Brief Introduction. Plasma 2018, 1, 5. [CrossRef]

10. Dong, Y.R.; Cheng, S.J.; Qi, G.H.; Yang, Z.P.; Yin, S.Y.; Chen, G.T. Antimicrobial and antioxidant activities of Flammulina velutipes polysaccharides and polysaccharide-iron(III) complex [corrected]. Carbohydr. Polym. 2017, 161, 26-32. [CrossRef]

11. Wu, D.-m.; Duan, W.-q.; Liu, Y.; Cen, Y. Anti-inflammatory effect of the polysaccharides of Golden needle mushroom in burned rats. Int. J. Biol. Macromol. 2010, 46, 100-103. [CrossRef] [PubMed]

12. Chang, H.-H.; Hsieh, K.-Y.; Yeh, C.-H.; Tu, Y.-P.; Sheu, F. Oral administration of an Enoki mushroom protein FVE activates innate and adaptive immunity and induces anti-tumor activity against murine hepatocellular carcinoma. Int. Immunopharmacol. 2010, 10, 239-246. [CrossRef] [PubMed]

13. Gu, Y.H.; Leonard, J. In vitro effects on proliferation, apoptosis and colony inhibition in ER-dependent and ER-independent human breast cancer cells by selected mushroom species. Oncol. Rep. 2006, 15, 417-423. [CrossRef] [PubMed]

14. Leung, M.Y.; Fung, K.P.; Choy, Y.M. The isolation and characterization of an immunomodulatory and anti-tumor polysaccharide preparation from Flammulina velutipes. Immunopharmacology 1997, 35, 255-263. [CrossRef]

15. Yi, C.; Zhong, H.; Tong, S.; Cao, X.; Firempong, C.K.; Liu, H.; Fu, M.; Yang, Y.; Feng, Y.; Zhang, H.; et al. Enhanced oral bioavailability of a sterol-loaded microemulsion formulation of Flammulina velutipes, a potential antitumor drug. Int. J. Nanomed. 2012, 7, 5067-5078.

16. Chang, Y.C.; Hsiao, Y.M.; Wu, M.F.; Ou, C.C.; Lin, Y.W.; Lue, K.H.; Ko, J.L. Interruption of lung cancer cell migration and proliferation by fungal immunomodulatory protein FIP-fve from Flammulina velutipes. J. Agric. Food Chem. 2013, 61, 12044-12052. [CrossRef]

17. Singleton, V.L.; Rossi, J.A. Colorimetry of Total Phenolics with Phosphomolybdic-Phosphotungstic Acid Reagents. Am. J. Enol. Vitic. 1965, 16, 144.

18. Chandra, S.; Khan, S.; Avula, B.; Lata, H.; Yang, M.H.; ElSohly, M.A.; Khan, I.A. Assessment of Total Phenolic and Flavonoid Content, Antioxidant Properties, and Yield of Aeroponically and Conventionally Grown Leafy Vegetables and Fruit Crops: A Comparative Study. Evid. Based Complement. Altern. Med. 2014, 2014, 253875. [CrossRef]

19. Chang, C.-C.; Yang, M.-H.; Wen, H.-M.; Chern, J.-C. Estimation of total flavonoid content in propolis by two complementary colorimetric methods. J. Food Drug Anal. 2002, 10, 178-182.

20. Brand-Williams, W.; Cuvelier, M.-E.; Berset, C. Use of a free radical method to evaluate antioxidant activity. LWT Food Sci. Technol. 1995, 28, 25-30. [CrossRef]

21. Adhikari, M.; Adhikari, B.; Kaushik, N.; Lee, S.-J.; Kaushik, N.K.; Choi, E.H. Melanoma Growth Analysis in Blood Serum and Tissue Using Xenograft Model with Response to Cold Atmospheric Plasma Activated Medium. Appl. Sci. 2019, 9, 4227. [CrossRef]

22. Baba, S.A.; Malik, S.A. Determination of total phenolic and flavonoid content, antimicrobial and antioxidant activity of a root extract of Arisaema jacquemontii Blume. J. Taibah Univ. Sci. 2015, 9, 449-454. [CrossRef]

23. Shimoi, K.; Masuda, S.; Shen, B.; Furugori, M.; Kinae, N. Radioprotective effects of antioxidative plant flavonoids in mice. Mutat. Res. Fund. Mol. M 1996, 350, 153-161. [CrossRef]

24. Alam, M.N.; Bristi, N.J.; Rafiquzzaman, M. Review on in vivo and in vitro methods evaluation of antioxidant activity. Saudi Pharm. J. 2013, 21, 143-152. [CrossRef]

25. Engida, A.M.; Faika, S.; Nguyen-Thi, B.T.; Ju, Y.H. Analysis of major antioxidants from extracts of Myrmecodia pendans by UV/visible spectrophotometer, liquid chromatography/tandem mass spectrometry, and high-performance liquid chromatography/UV techniques. J. Food Drug Anal. 2015, 23, 303-309. [CrossRef]

26. Zhao, M.; Yang, B.; Wang, J.; Li, B.; Jiang, Y. Identification of the major flavonoids from pericarp tissues of lychee fruit in relation to their antioxidant activities. Food Chem. 2006, 98, 539-544. [CrossRef]

27. Lin, H.-W.; Hsieh, M.-J.; Yeh, C.-B.; Hsueh, K.-C.; Hsieh, Y.-H.; Yang, S.-F. Coronarin D induces apoptotic cell death through the JNK pathway in human hepatocellular carcinoma. Environ. Toxicol. 2018, 33, 946-954. [CrossRef]

28. Ryu, S.; Lim, W.; Bazer, F.W.; Song, G. Chrysin induces death of prostate cancer cells by inducing ROS and ER stress. J. Cell. Physiol. 2017, 232, 3786-3797. [CrossRef] 
29. Zhang, S.; He, Y.; Tong, Q.; Chen, Q.; Wu, X.; Huang, W. Deltonin induces apoptosis in MDA-MB-231 human breast cancer cells via reactive oxygen species-mediated mitochondrial dysfunction and ERK/AKT signaling pathways. Mol. Med. Rep. 2013, 7, 1038-1044. [CrossRef]

30. Leibowitz, B.; Yu, J. Mitochondrial signaling in cell death via the Bcl-2 family. Cancer Biol. Ther. 2010, 9, 417-422. [CrossRef]

31. Youle, R.J.; Strasser, A. The BCL-2 protein family: Opposing activities that mediate cell death. Nat. Rev. Mol. Cell Biol. 2008, 9, 47-59. [CrossRef] [PubMed]

32. Patel, S.; Goyal, A. Recent developments in mushrooms as anti-cancer therapeutics: A review. 3 Biotech 2012, 2, 1-15. [CrossRef] [PubMed]

33. Ayeka, P.A. Potential of Mushroom Compounds as Immunomodulators in Cancer Immunotherapy: A Review. Evid. Based Complement. Altern. Med. 2018, 2018, 7271509. [CrossRef] [PubMed]

34. Blagodatski, A.; Yatsunskaya, M.; Mikhailova, V.; Tiasto, V.; Kagansky, A.; Katanaev, V.L. Medicinal mushrooms as an attractive new source of natural compounds for future cancer therapy. Oncotarget 2018, 9, 29259-29274. [CrossRef]

35. Pérez-Pizá, M.C.; Prevosto, L.; Grijalba, P.E.; Zilli, C.G.; Cejas, E.; Mancinelli, B.; Balestrasse, K.B. Improvement of growth and yield of soybean plants through the application of non-thermal plasmas to seeds with different health status. Heliyon 2019, 5, e01495. [CrossRef]

36. Randeniya, L.K.; de Groot, G.J.J.B. Non-Thermal Plasma Treatment of Agricultural Seeds for Stimulation of Germination, Removal of Surface Contamination and Other Benefits: A Review. Plasma Process. Polym. 2015, 12, 608-623. [CrossRef]

37. Dampier, K.; Hudson, E.A.; Howells, L.M.; Manson, M.M.; Walker, R.A.; Gescher, A. Differences between human breast cell lines in susceptibility towards growth inhibition by genistein. Br. J. Cancer 2001, 85, 618-624. [CrossRef]

38. Hu, H.; Zhang, Z.; Lei, Z.; Yang, Y.; Sugiura, N. Comparative study of antioxidant activity and antiproliferative effect of hot water and ethanol extracts from the mushroom Inonotus obliquus. J. Biosci. Bioeng. 2009, 107, 42-48. [CrossRef]

39. Jeong, J.W.; Jin, C.Y.; Park, C.; Hong, S.H.; Kim, G.Y.; Jeong, Y.K.; Lee, J.D.; Yoo, Y.H.; Choi, Y.H. Induction of apoptosis by cordycepin via reactive oxygen species generation in human leukemia cells. Toxicol. In Vitro 2011, 25, 817-824. [CrossRef]

40. Sznarkowska, A.; Kostecka, A.; Meller, K.; Bielawski, K.P. Inhibition of cancer antioxidant defense by natural compounds. Oncotarget 2017, 8, 15996. [CrossRef]

41. Stepanic, V.; Gasparovic, A.C.; Troselj, K.G.; Amic, D.; Zarkovic, N. Selected attributes of polyphenols in targeting oxidative stress in cancer. Curr. Top. Med. Chem. 2015, 15, 496-509. [CrossRef] [PubMed]

42. Chian, S.; Li, Y.-Y.; Wang, X.-J.; Tang, X.-W. Luteolin sensitizes two oxaliplatin-resistant colorectal cancer cell lines to chemotherapeutic drugs via inhibition of the Nrf2 pathway. Asian Pac. J. Cancer Prev. 2014, 15, 2911-2916. [CrossRef] [PubMed]

43. Chien, S.Y.; Wu, Y.C.; Chung, J.G.; Yang, J.S.; Lu, H.F.; Tsou, M.F.; Wood, W.G.; Kuo, S.J.; Chen, D.R. Quercetin-induced apoptosis acts through mitochondrial- and caspase-3-dependent pathways in human breast cancer MDA-MB-231 cells. Hum. Exp. Toxicol. 2009, 28, 493-503. [CrossRef] [PubMed]

44. Lambert, J.D.; Elias, R.J. The antioxidant and pro-oxidant activities of green tea polyphenols: A role in cancer prevention. Arch. Biochem. Biophys. 2010, 501, 65-72. [CrossRef]

45. Wang, Y.; Xu, G.; Tang, X.; Chen, H. Polysaccharide lentinan extracted from the stipe of Lentinus edodes mushroom exerts anticancer activities through the transcriptional regulation of cell cycle progression and metastatic markers in human colon cancer cells. Faseb. J. 2017, 31, lb391.

Publisher's Note: MDPI stays neutral with regard to jurisdictional claims in published maps and institutional affiliations. 